\title{
Surgical treatment of active infectious endocarditis: a study of 361 surgical cases
}

Tratamento cirúrgico da endocardite infecciosa ativa: análise de 361 doentes operados

Altamiro Ribeiro DIAS ${ }^{1}$, Pablo M. POMERANTZEFF ${ }^{1}$, Carlos Manoel A. BRANDÃO ${ }^{1}$, Ricardo Ribeiro DIAS ${ }^{1}$, Max GRINBERG ${ }^{1}$, Eliecer Villamizer de LAHOZ $^{1}$, Sérgio Almeida de OLIVEIRA ${ }^{1}$

RBCCV $44205-633$

\section{Abstract}

Objective: To report on the experience achieved with the surgical treatment of 361 patients with acute infectious endocarditis who were operated on in the Heart Institute of the University of São Paulo.

Method: The ages of the patients ranged from 3 to 81 years, with an average age of $38 \pm 8.3$ years. There were 230 male patients. It was possible to identify the etiologic agent in $311(86.20 \%)$ patients. The diagnosis of acute infectious endocarditis was obtained by clinical, echocardiographic and microbiological evaluations. Two hundred and five patients had lesions of heart valves and 156 patients had lesions of cardiac valvular prostheses. Ninety had annular abscesses and 11 had fistulae. Of the group of diseased native valves, $104(50.73)$ were operated on because of severe heart failure and $87(\mathbf{4 2 . 4 4 \% )})$ because of progressive sepsis. All natural aortic valves (136) were replaced by artificial valves. There were 107 diseased native mitral valves. In this group partial resections of infected tissue (vegetations) were carried out in 13 patients while maintaining the valvar apparatus. Of the 16 infected tricuspid valves, 8 were replaced. All the prosthese were substituted. The abscesses were cleaned and closed when their diameter was less than $10 \mathrm{~mm}$. The larger abscesses were cleaned and closed with a pericardial graft, which was the support for the artificial valve.

Results: There were $75(20.78 \%)$ hospital deaths, most of which caused by heart problems and their complications. There were 15 cases of postoperative endocarditis, 10 of which were re-operated on. The late follow-up showed good functional and clinical results, with $222(\mathbf{7 7 . 6 2 \% )}$ ) patients as NYHA Class I.

Conclusions: When indicated, the surgical treatment must be instituted as early as possible. All diseased and infected tissue must be removed to achieve good results.

Descriptors: Endocarditis, surgery. Heart valves, surgery. Abscess, heart valves.

\section{Resumo}

Objetivo: $O$ trabalho analisa a experiência obtida com o tratamento cirúrgico da endocardite infecciosa ativa (EIA) realizado em 361 doentes operados.

Método: As idades variaram de 3 a 81 anos com média de $38 \pm 8,3$ anos, sendo 230 pacientes do sexo masculino. Os agentes etiológicos foram identificados em $311(86,20 \%)$

Work performed in the Instituto do Coração do Hospital das Clínicas of the Medical School of the University of São Paulo. São Paulo, SP, Brazil

1 - From the Instituto do Coração do Hospital das Clínicas of the Medical School of the University of São Paulo. São Paulo, SP, Brazil. Correspondence address: Dr. Altamiro Ribeiro Dias. Instituto do Coração HC - FMUSP. Av. Dr. Enéas de Carvalho Aguiar, 44. São Paulo, SP, Brazil. CEP 05403-000. Phone/fax: (11) 3069-5415.

E-mail: dci_altamiro@incor.usp.br 
doentes, sendo o diagnóstico baseado no quadro clínico, ecocardiográfico e microbiológico. Duzentos e cinco doentes apresentavam comprometimento em valvas nativas e $156 \mathrm{em}$ próteses. Noventa doentes apresentavam abscessos anulares e 11 apresentavam fístulas. Deste grupo de 205 pacientes, 104 $(50,73 \%)$ foram operados por insuficiência cardíaca incontrolável e $87(42,44 \%)$ devido a sepsis progressiva. Todas as valvas aórticas infectadas (136) foram substituídas. Das as 107 valvas mitrais doentes, foram possíveis ressecções isoladas de vegetações em 13 pacientes. De 16 valvas tricúspides comprometidas, foram ressecadas oito e realizada ressecção parcial nas demais. As 156 próteses foram substituídas, a maioria por biopróteses. Os abscessos foram tratados por sutura direta, quando de diâmetros menores que $10 \mathrm{~mm}$.

\section{INTRODUCTION}

WALLACE et al. [1] published in 1965 a report of a patient with active infectious endocarditis (AIE), who, due to the persistent fever and progressive aortic failure, was submitted to surgical treatment with the replacement of the aortic valve and successful removal of the focus of the infection.

In 1986, we presented [2] the experience of the Heart Institute, Hospital das Clinicas of the Medical school in São Paulo (InCor) and from then until the present time, the number of patients operated on for AIE in our institution has increased greatly.

In this work we analyzed some aspects of this disease, as well as the results of the surgical treatment of AIE of a total of 361 operated patients.

\section{METHOD}

The results of a total of 361 patients operated on for AIE in InCor over a period of 19 years were evaluated.

The diagnosis of endocarditis was based on the clinical history of the patient, blood cultures and echocardiographic studies. The cultures were positive in $311(86.20 \%)$ of the patients. The identified agents are shown in Table 1.

Table 1. Active infectious endocarditis: surgical treatmen Identified etiological agents

\begin{tabular}{lll}
\hline Name & $\mathrm{N}^{\mathrm{o}}$ & $\%$ \\
\hline S.Viridans & 75 & 24,20 \\
S. Aureus & 50 & 16,10 \\
Streptococcus sp. & 45 & 14,41 \\
Enterococcus & 35 & 11,20 \\
Cocos G+ & 31 & 10,17 \\
S.Epidermidis & 26 & 8,47 \\
Fungi & 21 & 6,78 \\
Other etiological agents & 28 & 8,73 \\
& & \\
Total & 311 & 100,06 \\
\hline
\end{tabular}

Quando maiores, foram limpos e ocluídos com retalhos de pericárdio bovino sobre os quais as próteses foram fixadas. As fístulas foram limpas e ocluídas nas duas extremidades.

Resultados: Houve 75 (20,78\%) óbitos imediatos e 26 tardios, a grande maioria devido a causas cardiogênicas. Houve 15 recidivas tardias, com necessidade de reoperação em 10 pacientes. $O$ seguimento tardio mostra uma recuperação funcional em $77,62 \%$ dos doentes.

Conclusões: $\mathrm{O}$ tratamento deve ser precoce e radical, ressecando-se todo e qualquer tecido comprometido, o que contribue para melhores resultados.

Descritores: Endocardite, cirurgia. Valvas cardíacas, cirurgia. Abscesso, valvas cardíacas.

The ages of the patients varied from 3 to 81 years with a mean of $38 \pm 83$ years, where 230 patients were male and 131 were female.

Two hundred and 5 patients presented with compromise of native valves, which included 136 aortic valves, 107 mitral valves and 16 tricuspid valves. Several of these patients presented with multiple valve impairment. One hundred and forty-two patients presented with compromise of bioprostheses and 14 of mechanical prostheses (Table 2).

Table 2. Active infectious endocarditis: surgical treatment Affected valves grouped by patient

\begin{tabular}{|c|c|c|}
\hline Native valves & $\mathrm{N}$ af putients & 5 of patiens \\
\hline Motic (Mo) & 84 & 40.98 \\
\hline Mtral (Mti) & \$s & 27.32 \\
\hline $\mathrm{Mi}+\mathbf{M O}$ & 48 & 2390 \\
\hline Tricuspid (I) & 13 & 6.34 \\
\hline $\mathrm{Mi}+\mathrm{AO}_{0}+\mathrm{T}$ & 2 & 0.98 \\
\hline$A_{0}+T$ & 1 & a.48 \\
\hline Toeal & 205 & 100.00 \\
\hline Biopruedhese & 142 & 91.03 \\
\hline Metallic prostheses & 14 & 897 \\
\hline Toeal & 156 & 100.00 \\
\hline
\end{tabular}

The patients with endocarditis in native valves presented with severe regurgitation in about $80 \%$ of the cases.

Figure 1 shows the functional class (NYHA) of the patients in the pre-operative period.

Ninety patients suffered from annular abscesses and 11 presented with fistulae.

The surgical indications of the 205 patients with native valve compromise were severe heart failure in $104(50.73 \%)$ individuals; failure of the etiologic treatment in 87 (42.44\%); embolic phenomenon in 7 (3.41\%); a fungal etiology in 5 (2.44\%); and other etiologies in $2(0.98 \%)$.

In the patients with artificial valves, the surgical indications obeyed the same criteria, with the artificial valve introducing an additional element in the indication of surgical treatment.

The surgical procedures complied with the basic methodological principles of complete eradication of all the 


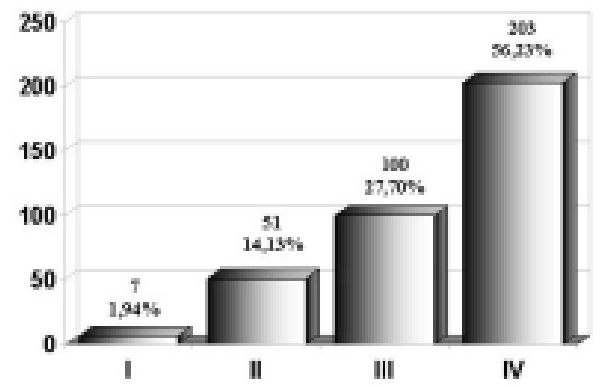

Fig. 1 - Active infectious endocarditis: surgical treatment Functional class - pre-operative period

growths, as well as the infected tissue surrounding the focus of the infection [3-6]

There was a necessity to replace the native aortic valves in 136 patients. The mitral valves were replaced in 94 individuals, with resection of the vegetation in isolation possible with another 13 mitral valves. Of the 16 infected tricuspid valves it was possible to partially resect the septal and/or posterior cuspids in 8 individuals, thus preserving the anterior cuspids. Bioprostheses were employed in 203 (99\%) of the patients.

Annular abscesses were found during surgery in 90 patients, where $66(73.34 \%)$ of these abscesses were equal to or less than $10 \mathrm{~mm}$ in diameter. In all these 66 abscesses it was possible to completely remove the purulent material with the resulting wounds treated with ethanolic iodine and occluded with a direct suturing after the implantation of the corresponding valvar prosthesis. In 43 patients these abscesses were on the aortic annuli and in 23 they were located in the mitral annuli.

In $24(26.66 \%)$ of the patients, the abscesses presented with diameters greater than $10 \mathrm{~mm}$, making the treatment more complex; 18 of these abscesses were found on aortic annuli and 6 on mitral annuli.

With wounds of greater than $10 \mathrm{~mm}$, after cleaning and treatment with ethanolic iodine, occlusion was achieved with a bovine pericardial membrane patch fixed in glutaraldehyde which was sutured onto the abscess cavity in all our cases, although other materials can be used for this purpose [7-9] The corresponding valvar prostheses were sutured on the previously fixed bovine pericardial patches.

Ten of these abscesses with diameters greater than $10 \mathrm{~mm}$ were located on aortic annuli and 6 in mitral annuli.

In 2 patients with large abscesses there was a discontinuity between the left ventricle and the aorta, which obliged the use of valved tubular grafts and re-implantation of the coronary arteries, the so-called valvar translocation, which was necessary given the intensity of the annular damage observed [10-14].

In 6 patients, of the group with large abscesses, there was severe compromise of the transition between the aortic and mitral valves. In these patients the surgical methodological principles as proposed by DAVID et al. [5] and ERGIN et al. [6] were followed, which can be summarized as follows:

a) Complete removal of the compromised structures, including the fibrous trigones, transforming the mitral-aortic region into a single orifice.

b) Reconstruction using a double triangular bovine pericardial membrane patches; one of these sheets is used to close the aortic root and the other to close the left atrium, suturing laterally to the remaining tissue of the fibrous trigones.

c) On the transition line created between the mitral and aortic annuli, segments corresponding to the aortic and mitral prostheses are sutured, thus restoring the mitral and aortic orifices.

In 11 patients fistulae were evidenced, with 6 from the aorta to the right atrium, 3 from the aorta to the right ventricle and 2 cases from the aorta to the left atrium.

All the courses of the fistulae were rigorously cleaned and closed with bovine pericardial patches sutured over the two orifices.

\section{RESULTS}

Table 3 reports the main complications that occurred in the immediate post-operative period.

Table 3. Active infectious endocarditis: surgical treatment Complications in the post-operative period

\begin{tabular}{|c|c|c|}
\hline Type af cramplication & $\mathrm{Ne}^{*}$ of cases & $\Leftrightarrow$ \\
\hline 100 oulput sporkome & 44 & 2603 \\
\hline Accten remal frivere & 50 & 17.55 \\
\hline Acte myociodial inlaretion & 17 & 10.06 \\
\hline Eleeding wilite-sperition & 16 & 947 \\
\hline Recidive endocordtis & 12 & 7.10 \\
\hline Ërotzipestumotia & 10 & 592 \\
\hline Septioemia & 9 & 5.33 \\
\hline Nenrobogial complicaticns & is & 473 \\
\hline Reeppiratary failary & is & 473 \\
\hline Multiple orgen tature & 7 & 4.14 \\
\hline botal strionertriculur block & 3 & 178 \\
\hline Alrid fitrilation & 3 & 1.78 \\
\hline Troentoembolism & 2 & 1.18 \\
\hline Total & 169 & 10000 \\
\hline
\end{tabular}

There were 75 (20.78\%) deaths in the immediate postoperative period, the causes of which are shown in Table 4 , but were predominantly related to cardiogenic problems. Of the 286 patients who were released from hospital, $225(78.67 \%)$ were accompanied for periods ranging from 18 to 200 months.

The patients presented with a considerable improvement in their functional class, as can be observed in Figure 2. In fact $222(77.62 \%)$ of the patients were functional class I after surgical treatment. 
Table 4. Active infectious endocarditis: surgical treatment Causes of hospital deaths

\begin{tabular}{|c|c|c|}
\hline Type of complieation & $\mathrm{N}^{\circ}$ af cases & 96 \\
\hline Low output syndrome & 26 & 34.67 \\
\hline Multiple organ failure & 21 & 2800 \\
\hline Septicemia & 13 & 17.34 \\
\hline Recidve endocarditia & 6 & 800 \\
\hline Respiratory fiulure & 3 & 4.00 \\
\hline Acule myocardial infirction & 2 & 267 \\
\hline Cardiac tampoesde & 1 & 1.33 \\
\hline Antrothmia & 1 & 1.33 \\
\hline Neurological complications & 1 & 1.33 \\
\hline Coagulopatily & 1 & 1.33 \\
\hline Total & 75 & 100.60 \\
\hline
\end{tabular}

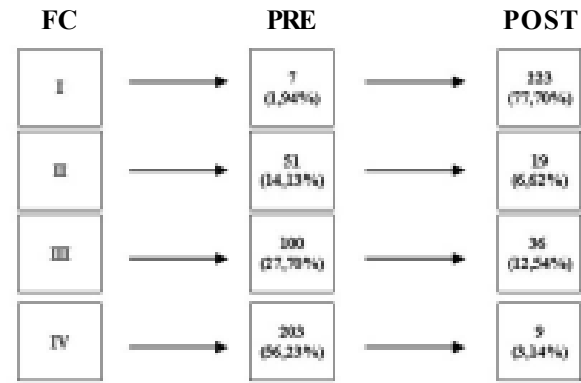

Fig. 2 - Active infectious endocarditis: surgical treatment Surgical treatment - functional class

Thirty-six late complications occurred, of which 15 were relapsed endocarditis. Ten of these patients required reoperations (Table 5).

Table 5. Active infectious endocarditis: surgical treatment Late complications

\begin{tabular}{|c|c|c|c|}
\hline Type of cemplicative & & No of canes & 96 \\
\hline E. L with ro-speratice & & 10 & 27.78 \\
\hline EL & & 5 & 13.39 \\
\hline Dysfunstions & Calcification & 10 & \\
\hline Valvar & PB ropture & 7 & $52 \pi$ \\
\hline with re-speration & Esciepe to - Valvar & 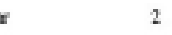 & \\
\hline Others & & 2 & 5.96 \\
\hline Tetal & & 36 & 106.90 \\
\hline
\end{tabular}

There were 26 late deaths, the majority of which $(73.07 \%)$ were due to heart failure (Table 6).

The global survival rate was $67.3 \pm 5.1 \%$ at 160 months (Figure 3 ) and the AIE-free survival rate was $92.3 \pm 2.8 \%$ (Figure 4 ).

Table 6. Active infectious endocarditis: surgical treatment Causes of late deaths

\begin{tabular}{lcr}
\hline Type of eamplication & $\mathrm{N}^{*}$ of ceses & $\%$ \\
\hline Heart failure & 19 & 73.07 \\
Acute myocardial infarction & 2 & 7.69 \\
Chronic renal failure & 2 & 7.69 \\
Sedden death & 1 & 3.85 \\
Endocarditis & 1 & 3.85 \\
Unknown & 1 & 3.85 \\
Tetal & $\mathbf{2 6}$ & $\mathbf{1 0 0 . 0 0}$ \\
\hline
\end{tabular}

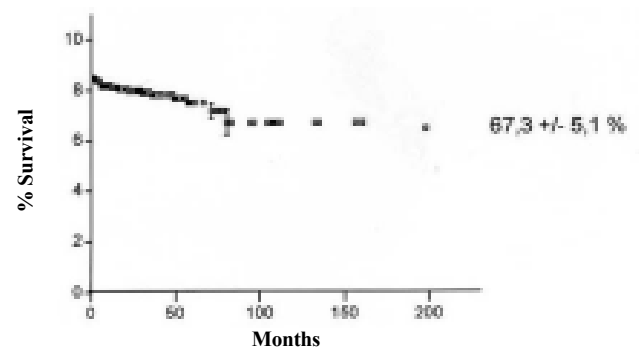

Fig. 3 - Actuarial curve free of endocarditis

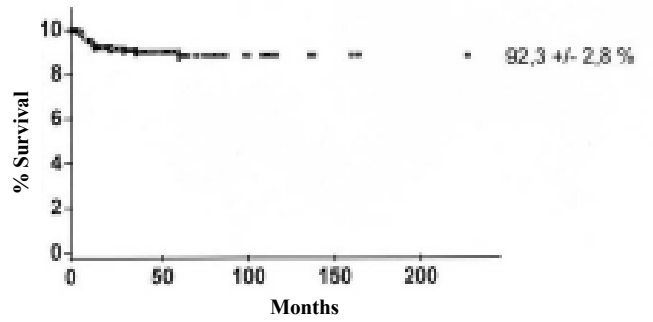

Fig. 4 - Survival curve free of endocarditis 


\section{COMMENTS}

Surgical treatment of AIE constitutes a great challenge as, not always, the post-operative examinations, in particular the echocardiographic studies, precisely demonstrate the total extension of the annulo-valvar infectious process, especially in patients with valvar prostheses, fistulae and multiple valve lesions.

Another factor that greatly aggravates the situation is the duration of the process. It is common for patients to arrive at InCor after months of suffering from symptoms and sometimes after inadequate antibiotic treatment.

There is a consensus in the literature that surgical treatment must be radical in the sense of removing all infected tissue, thus the surgeon can not concern himself with the extension of the tissues to be removed [4,5,7,10,15-17]. Not to comply with this basic principle is to be certain of relapse and its consequences. In our work and in particular over the last ten years, these principles have been observed rigorously. The surgeon, sometimes, has to use his resourcefulness for the reconstruction that is necessary, using skill [4] and improvisation. The important thing is the reconstruction of the function without septic residue.

In our casuistic there were 24 large abscesses with diameters greater than $10 \mathrm{~mm}$ for which, after cleaning and removal of all the infected tissue, bovine pericardial patches fixed in glutaraldehyde were required. Through these patches sutures are employed in order to fix the respective prostheses. In 2 patients, abscesses affected $2 / 3$ of the aortic annulus.

In another 2 patients, the annular damage associated to previous reoperations compromised the aortic annulus in such a way as to compel the utilization of valved tubes in the supracoronary position and concomitant coronary artery bypass grafting [10].

In 13 mitral valves, the lesions were small and focal constituting of vegetative points the majority of which ( 9 valves) were located on the anterior cuspid, with the possibility of their removal giving a good result.

In 8 tricuspid valves, removal was partial, the septal cuspid in 6 and the septal and posterior cuspids in 2 . The remaining anterior cuspids were sufficient to guarantee a good functional result with negligible hemodynamic reflux [18]

In one of the eight patients submitted to resection and implantation of bioprostheses in the tricuspid position, there was relapse of the infectious process by $P$. aeruginosa. The patient was re-operated and the annulus was found to be severely compromised. The prosthesis was dried out and another was not implanted in its place, as was proposed by ARBULU \& ASFAW in 1981 [19].

Occlusion of the fistulae was achieved with bovine pericardial patches fixed in both orifices, after cleaning the fistulous course. There are published reports of the use of fresh autologous pericardium with a good result [10]

We consider our hospital mortality rate of $20.77 \%$ ( 75 of the total cases) as high, although this fact bears a direct relation to the condition that many patients arrive in our hospital, with severe cardiovascular compromise, sepsis, abscesses, etc. These factors are predictors of a higher surgical risk that is always accompanied by a greater morbidmortality rate [20-24].

Our experience demonstrates that the best results are obtained in cases which are correctly indicated for surgery at an early stage, combined with astuteness of the physician and the experience of the surgeon to perform adequate treatment within the principles and norms summarized herein.

\section{CONCLUSION}

The predominant indication for surgery $(50.73 \%)$ was the presence of severe heart failure, resistant to correctly established clinical treatment, followed by a persistent septic state $(42.43 \%)$.

Surgical treatment should be radical, completely removing all the infected tissue, without which relapse in inevitable.

Reconstruction of the affected structures should be performed with technical rigor in order to obtain the best functional result possible.

Hospital and late morbidity and mortality are closely related to cardiovascular events.

The majority of surviving patients $(77.62 \%)$ fully recover normal functional conditions.

\section{BIBLIOGRAPHIC REFERENCES}

1. Wallace AG, Young Jr. WG, Osterhout S. Treatment of acute bacterial endocarditis by valve excision and replacement. Circulation 1963; 31: 450-3.

2. Dias AR, Grinberg M, Mansur A, Pomerantzeff PM, Verginelli G, Zerbini EJ et al. Avaliação dos resultados do tratamento cirúrgico da endocardite infecciosa na fase ativa da doença. Arq Bras Cardiol 1986; 47: 275-8.

3. Rumisek JD, Berry WR, Barry MJ, Clarke JS. Transseptal control of the difficult aortic annulus. Ann Thorac Surg 1985; 39: 385-6.

4. Borst HG. Repair of septic aortic root defects without conduit. J Card Surg 1990; 5: 44-7. 
5. David TE, Feindel CM, Armstrong S, Sun Z. Reconstruction of the mitral anulus. J Thorac Cardiovasc Surg 1995; 110: $1323-32$

6. Ergin MA, Raissi S, Follis F, Lansman SL, Griepp RB. Annular destruction in acute bacterial meet the challenge. J Thorac Cardiovasc Surg 1989; 97: 755-63.

7. Symbas PN, Vlasis SE, Zacharopoulos L, Lutz JF. Acute endocarditis: surgical treatment of aortic regurgitation and aortico-left ventricular discontinuity. J Thorac Cardiovasc Surg 1982; 84: 291-6.

8. Fiore AC, Ivey TD, McKeown PP, Misbach GA, Allen MD, Dillard DH. Patch closure of aortic annulus mycotic aneurysms. Ann Thorac Surg 1986; 42: 372-9.

9. De Brux JL, Subayi JB, Caliani JA, Huass U, Popoff G, Pansard Y et al. Traitement chirurgical de l'endocardite infectieuse sur valve native: a propos de 71 cas. Arch Mal Coeur Vaiss 1988; 81:43-8.

10. Jault F, Gandjbakhch I, Chastre JC, Levasseur JP, Bors V, Gibert $C$ et al. Prosthetic valve endocarditis with ring abscesses: surgical management and long-term results. J Thorac Cardiovasc Surg 1993; 105: 1106-13.

11. Lau JK, Robles A, Cherian A, Ross DN. Surgical treatment of prosthetic endocarditis: aortic root replacement using a homograft. J Thorac Cardiovasc Surg 1984; 87: 712-6.

12. Ross D. Allograft root replacement for prosthetic endocarditis. J Card Surg 1990; 5: 68-72.

13. Dearani JA, Orszulak TA, Schaff HV, Daly RC, Anderson BJ, Danielson GK. Results of allograft aortic valve replacement for complex endocarditis. J Thorac Cardiovasc Surg 1997; 113: 285-91

14. Danielson GK, Titus JL, DuShane JW. Successful treatment of aortic valve endocarditis and aortic root abscesses by insertion of prosthetic valve in ascending aorta and placement of bypass grafts to coronary arteries. J Thorac Cardiovasc Surg 1974; 67: 443-9.
15. d'Udekem Y, David TE, Feindel CM, Armstrong S, Sun Z. Long-term results of surgery for active infective endocarditis. Eur J Cardiothorac Surg 1997; 11: 46-52.

16. Netzer RO, Zollinger E, Seiler C, Cerny A. Infective endocarditis: clinical spectrum, presentation and outcome. An analysis of 212 cases 1980-1995. Heart 2000; 84:25-30.

17. Knosalla C, Weng Y, Yankah AC, Siniawski H, Hofmeister J, Hammerschmidt R et al. Surgical treatment of active infective aortic valve endocarditis with associated periannular abscess11 year results. Eur Heart J 2000; 21: 490-7.

18. Arbulu A. Trivalvular/bivalvular heart: a philosophical, scientific and therapeutic concept. J Heart Valve Dis 2000; 9: 353-8.

19 Arbulu A, Asfaw A. Tricuspid valvulectomy without prosthetic replacement: ten years of clinical experience. J Thorac Cardiovasc Surg 1981; 82: 684-91.

20. Mullany CJ, Chua YL, Schaff HV, Steckelberg JM, Ilstrup DM, Orszulak TA et al. Early and late survival after surgical treatment of culture-positive active endocarditis. Mayo Clin Proc 1995;70: 517-25.

21. Choussat R, Thomas D, Isnard R, Michel PL, Iung B, Hanani $\mathrm{G}$ et al. Perivalvular abscesses associated with endocarditis; clinical features and prognostic factors of overall survival in series of 233 cases. Perivalvular Abscesses French Multicentre Study. Eur Heart J 1999; 20: 232-41.

22. Alexiou C, Langley SM, Stafford H, Lowes JA, Livesey SA, Monro JL. Surgery for active culture-positive endocarditis: determinant of early and late outcome. Ann Thorac Surg 2000; 69:1448-54.

23. Peric M, Vuk F, Huskic R, Lausevic-Vuk L, Neskovic AN, Borzanovic M, Bojic M. Active infective endocarditis: low mortality associated with early surgical treatment. Cardiovasc Surg 2000;8: 208-13.

24. Gordon SM, Serkey JM, Longworth DL, Lytle BW, Cosgrove DM 3rd. Early onset prosthetic valve endocarditis: the Cleveland Clini experience 1992-1997. Ann Thorac Surg 2000; 69: 1388-92. 